\title{
Analisis Ketidakpatuhan Pengobatan Pasien TB-MDR Fase Intensif Di Rumah Sakit X Surakarta
}

\section{Analysis of Non Adherence The Treatment of TB-MDR Intensive Phase Patients at RS X Surakarta}

\author{
Farid Setyo Nugroho \\ Program Studi Kesehatan Masyarakat \\ Universitas Veteran Bangun Nusantara Sukoharjo \\ Email :faridsetyo25@gmail.com
}

\begin{abstract}
ABSTRAK
Latar Belakang:Faktor penyebab kekebalan Myobacterium tuberculose terhadap Obat Anti TB (OAT) adalah perilaku manusia, baik penyedia layanan, pasien, maupun program atau sistem layanan kesehatan yang berakibat terhadap tatalaksana pengobatan pasien TB yang tidak sesuai dengan standar dan mutu yang ditetapkan. Ketidakpatuhan untuk berobat secara teratur bagi penderita TB tetap menjadi sebuah hambatan untuk mencapai angka kesembuhan yang tinggi. Tingginya angka putus obat akan meningkatkan jumlah kasus TB-MDR dan bertambah lamanya masa pengobatan.

Metode: Penelitian ini menggunakan metode mix method, secara kuantitatif menggunakan rancangan cross sectional, secara kualitatif dengan studi kasus.

Hasil: Terdapat hubungan antara sikap dengan ketidakpatuhan pengobatan TB MDR dimana $\mathrm{p}$ value sebesar 0,002 . Tidak terdapat hubungan antara pengetahuan, efek samping obat dan dukungan keluarga dengan ketidakpatuhan pengobatan TB MDR, dimana $p$ value $>0,050$.

Kesimpulan: Terdapat hubungan antara sikap dengan ketidakpatuhan pengobatan TB MDR. Tidak terdapat hubungan antara pengetahuan, efek samping dan dukungan keluarga dengan ketidakpatuhan pengobatan TB MDR.
\end{abstract}

Kata kunci : TB, Ketidakpatuhan, Pengobatan

\begin{abstract}
Background: Factors causing the immunity of Mycobacterium tuberculosis is human behavior, both service providers, patients, and health service programs or systems that result in treatment of TB patients who are inconsistent with established standards and provision. Non-adherence to regular treatment for TB patients remains a border to achieving high cure rates. High rates of drug will increase the number of TB-MDR cases and increasing the duration of treatment.

Method: This research uses mix method method, quantitatively using cross sectional design, qualitatively with case study.

Result: There is a related between attitude with TB-MDR treatment non-adherence where $\mathrm{p}$ value is 0.002 . There is no related between knowledge, drug side effects and family support with TB-MDR treatment non-adherence, where $\mathrm{p}$ value $>0.050$.
\end{abstract}

Keyword: TB, Non adherence, Treatment 


\section{PENDAHULUAN}

Secara global menurut World Health Organization (WHO) memperkirakan proporsi kasus baru TB-MDR pada tahun 2013 sebesar 3,5\%, hal ini berarti bahwa sebanyak 480.000 kasus baru TB-MDR telah terjadi di seluruh dunia. Kematian akibat TB-MDR di seluruh dunia sebesar 210.00 orang. Angka keberhasilan pengobatan TB-MDR masih rendah, secara global angka keberhasilan pengobatan hanya sebesar $48 \%$ dari target keberhasilan sebesar $85 \%$.

Indonesia berada pada peringkat 8 dari 27 negara yang memilki beban kasus TBMDR dengan perkiraan penderita sebesar 6.900, yaitu 1,9\% dari kasus baru dan $12 \%$ dari kasus pengobatan ulang. Pada tahun 2013 proporsi kasus baru TB-MDR di Indonesia sebesar 1,9\%. Tren kasus TB-MDR di Indonesia terus naik dari tahun ke tahun. Berdasarkan hasil uji laboratorium yang dilakukan, pada tahun 2013 diketahui sebanyak 921 orang terkonfirmasi TB-MDR dengan pasien yang sedang menjalani pengobatan sebanyak 809 orang. Masih banyaknya orang yang belum menjalani pengobatan merupakan permasalahan yang besar, karena pasien yang tidak menjalani pengobatan akan meningkatkan resiko kematian dan penularan TB-MDR.

Lima provinsi terbanyak yang mengobati TB dengan obat program adalah DKI Jakarta (68.9\%). DI Yogyakarta (67,3\%), Jawa Barat (56,2\%), Sulawesi Barat $(54,2 \%)$ dan Jawa Tengah (50.4\%). Sedangkan Lima provinsi dengan TB paru tertinggi di Indonesia adalah Jawa Barat (0.7\%), Papua (0.6\%), DKI Jakarta (0.6\%), Gorontalo (0.5\%), Banten $(0.4 \%)$ dan Jawa Tengah $(0.4 \%)$.

Angka kesembuhan TB di Jawa Tengah masih sebesar 81,46\%, hal menunjukkan bahwa angka kesembuhan TB di Jawa Tengah masih dibawah target nasional sebesar $85 \%$. Permasalahan kekebalan ganda terhadap OAT juga terjadi di Jawa Tengah, dimana terdapat 59 kasus TB-MDR. Diantaranya adalah di Soloraya sebanyak 21 kasus, Eks Karesidenan Kedu 5 kasus, Eks Karesidenan Semarang 8 kasus, Eks Karesidenan Pati 15 kasus, Eks Karesidenan Pekalongan 2 kasus, dan Eks Karesidenan Banyumas 8 kasus.

Provinsi Jawa Tengah memiliki 2 rumah sakit sebagai rujukan penanganan pasien TB-MDR. Salah satu rumah sakit yang menjadi rujukan adalah Rumah Sakit Umum Daerah (RSDM) DR. Moewardi Surakarta. Berdasarkan data yang didapatkan 3 tahun terkahir di RSUD DR. Moewardi Surakarta diketahui sebanyak 269 pasien dengan TB-MDR menjalani program pengobatan TB-MDR, $13 \%$ pasien drop out dan $11 \%$ pasien meninggal. Pasien yang menjalani program pengobatan di RSUD DR. Moewardi Surakarta berasal dari wilayah Jawa Tengah bagian timur dan wilayah Jawa Timur bagian barat, sehingga jumlah yang ditangani cukup banyak.

Faktor penyebab terjadinya resistensi kuman terhadap Obat Anti TB (OAT) adalah perilaku manusia, baik penyedia layanan, pasien, maupun program atau sistem layanan kesehatan yang berakibat terhadap tatalaksana pengobatan pasien TB yang tidak sesuai dengan standar dan mutu yang ditetapkan. Ketidakpatuhan untuk berobat secara teratur bagi penderita TB tetap menjadi hambatan untuk mencapai angka kesembuhan yang tinggi. Tingginya angka putus obat mengakibatkan tingginya kasus TB-MDR dan akan membutuhkan biaya yang lebih besar serta bertambah lamanya pengobatan.

\section{METODE}

Penelitian ini menggunakan metode mix method, secara kuantitatif menggunakan rancangan cross sectional. Sedangkan secara kualitatif dengan studi kasus untuk mengetahui alasan atau penyebab pasien TB MDR tidak melanjutkan (putus pengobatan).

Populasi dan sampel dalam pendekatan kuantitatif adalah pasien TB MDR yang sedang berada dalam fase intensif sejumlah 28 pasien di RSDM Surakarta. Sedangkan objek atau 
informan pendekatan kualitatif adalah pasien TB MDR yang tidak bersedia melanjutkan (putus) pengobatan TB MDR di RSDM Surakarta sejumlah 3 informan. Pengambilan sampel dalam penelitian ini menggunakan teknik purposive sampling.

\section{HASIL DAN PEMBAHASAN}

\section{Kuantitatif}

a. Univariat

1) Karakteristik responden

Tabel 1. Distribusi Frekuensi berdasarkan karakteristik responden.

\begin{tabular}{lcc}
\hline \multicolumn{1}{c}{ Karakteristik } & F & $\%$ \\
\hline Umur & 27 & 96 \\
Produktif & 1 & 4 \\
Non Produktif & 16 & 57 \\
Jenis kelamin & 12 & 43 \\
$\quad$ Laki-laki & & \\
$\quad$ Perempuan & 11 & 39 \\
Tingkat pendidikan & 17 & 61 \\
$\quad$ Tinggi & & \\
$\quad$ Rendah & 26 & 93 \\
Tingkat pendapatan & 2 & 7 \\
$\quad$ Rendah & & \\
$\quad$ Tinggi & 25 & 89 \\
Status pekerjaan & 3 & 11 \\
$\quad$ Tidak bekerja & & \\
$\quad$ Bekerja & 28 & 100 \\
$\quad$ Total &
\end{tabular}

Berdasarkan tabel.1 diketahui bahwa sebagian besar responden termasuk dalam kelompok umur produktif $96 \%$, berjenis kelamin laki-laki 57\%, tingkat pendidikan yang rendah $61 \%$, pendapatan rendah $93 \%$, dan tidak bekerja sebesar $89 \%$.

2) Pengetahuan responden

Tabel 2. Distribusi frekuensi pengetahuan responden

\begin{tabular}{|l|c|c|}
\hline $\begin{array}{c}\text { Kategori Tingkat } \\
\text { Pengetahuan tentang } \\
\text { penyakit TB }\end{array}$ & F & $\%$ \\
\hline Kurang (skor < median) & 13 & 45 \\
\hline Baik (skor $\geq$ median) & 15 & 55 \\
\hline \multicolumn{1}{|c|}{ Total } & 28 & 100 \\
\hline $\begin{array}{l}\text { Mean: } 16,21 \\
\text { Median: } 17 \\
\text { Min-Max: } 8-19\end{array}$ \\
\hline \multicolumn{2}{|l}{} \\
\hline
\end{tabular}

Berdasarkan tabel 2 menunjukkan bahwa responden yang memiliki pengetahuan yang baik tentang penyakit TBC sebesar 15 responden (55\%). Responden yang memiliki pengetahuan kurang tentang penyakit $\mathrm{TBC}$ sebesar 13 responden (45\%). Rata-rata nilai 
pengetahuan responden adalah 16,21 dengan nilai tengah 17 . Nilai pengetahuan yang paling rendah adalah 8 dan paling tinggi 19 .

3) Sikap

Tabel 3. Distribusi frekuensi sikap responden

\begin{tabular}{|l|c|c|}
\hline \multicolumn{1}{|c|}{ Sikap } & F & \% \\
\hline Kurang Baik (skor < median) & 14 & 50 \\
\hline Baik (skor $\geq$ median) & 14 & 50 \\
\hline \multicolumn{1}{|c|}{ Total } & 28 & 100 \\
\hline $\begin{array}{l}\text { Mean:20,14 } \\
\text { Median: 20,50 } \\
\text { Min-Max: 15-21 }\end{array}$ \\
\hline
\end{tabular}

Berdasarkan tabel 3 menunjukkan bahwa sebesar 14 (50\%) responden memilik sikap yang baik terhadap pengobatan TBC. Responden yang memiliki sikap kurang terhadap pengobatan TBC sebesar 14 (50\%) responden. Rata-rata nilai responden 20,14 dengan nilai median 21, nilai sikap responden yang paling rendah adalah 15 dan paling tinggi 21 .

4) Efek samping OAT

Tabel 4. Distribusi efek samping OAT responden

\begin{tabular}{|l|c|c|}
\hline \multicolumn{1}{|c|}{ Efek Samping } & F & \% \\
\hline Banyak (skor $\geq$ mean) & 13 & 46 \\
\hline Sedikit (skor < mean) & 15 & 54 \\
\hline \multicolumn{1}{|l|}{ Total } & 28 & 100 \\
\hline $\begin{array}{l}\text { Mean:5,46 } \\
\text { Median: 5 } \\
\text { Min-Max: 2-8 }\end{array}$ \\
\hline
\end{tabular}

Berdasarkan tabel 4 menunjukkan bahwa sebesar 13 (46\%) responden mengalami efek samping yang banyak dan 15 (54\%) responden mengalami efek samping sedikit.

Tabel 5. Distribusi banyaknya efek samping yang dirasakan responden

\begin{tabular}{|l|c|}
\hline \multicolumn{1}{|c|}{ EFEK SAMPING } & $\begin{array}{c}\text { Jumlah } \\
\text { responden } \\
\text { yang } \\
\text { merasakan }\end{array}$ \\
\hline Gangguan penglihatan & 12 \\
\hline Nyeri perut / mual / muntah & 27 \\
\hline Kulit gatal-gatal / kemerahan & 18 \\
\hline Demam / menggigil & 13 \\
\hline Nyeri sendi / otot & 23 \\
\hline Sakit kepala / pusing & 23 \\
\hline $\begin{array}{l}\text { Kesemutan sampai dengan rasa } \\
\text { terbakar di kaki }\end{array}$ & 19 \\
\hline Gangguan pendengaran & 18 \\
\hline
\end{tabular}

Berdasarkan tabel 5 efek samping yang banyak dirasakan oleh responden adalah mual dan muntah sebanyak 27 responden, nyeri sendi dan otot sebanyak 23 responden, dan pusing sebanyak 23 responden. 
5) Dukungan keluarga

Tabel 6. Distribusi frekuensi dukungan keluarga

\begin{tabular}{|c|c|c|}
\hline Dukungan Keluarga & $\mathbf{F}$ & $\%$ \\
\hline Mendukung & 19 & 68 \\
\hline Tidak mendukung & 9 & 32 \\
\hline Total & 28 & 100 \\
\hline \multicolumn{3}{|l|}{$\begin{array}{l}\text { Mean: } 17,32 \\
\text { Median: } 18 \\
\text { Min - Max: } 12-18\end{array}$} \\
\hline
\end{tabular}

Tabel 6 menunjukkan bahwa sebesar 19 (68\%) responden mendapatkan dukungan keluarga selama menjalani pengobatan TB MDR, dan sebesar $9(32 \%)$ responden tidak mendapatkan dukungan dari keluarga selama menjalani pengobatan TB MDR.

b. Bivariat

Tabel 2. Hasil analisis bivariat antara variabel dependen dengan independen

\begin{tabular}{|c|c|c|}
\hline Variabel & Nilai $p$ & Keterangan \\
\hline Pengetahuan & 0,456 & $\begin{array}{c}\text { Tidak } \\
\text { Signifikan }\end{array}$ \\
\hline Sikap & 0,002 & Signifikan \\
\hline $\begin{array}{l}\text { Efek samping } \\
\text { OAT } \\
\text { Dukungan } \\
\text { keluarga } \\
\end{array}$ & 0,070 & $\begin{array}{c}\text { Tidak } \\
\text { Signifikan } \\
\text { Tidak } \\
\text { Signifikan } \\
\end{array}$ \\
\hline
\end{tabular}

Berdasarkan tabel.2 diketahui bahwa terdapat hubungan antara variabel sikap dengan ketidakpatuhan pengobatan TB MDR dimana nilai $p$ value sebesar 0,002. Sedangkan variabel Pengetahuan, Efek samping OAT, dan dukungan keluarga tidak terdapat hubungan dengan nilai $\mathrm{p}$ value $>0,05$.

\section{Kualitatif}

Berdasarkan keterangan dari informan $\mathrm{P}$ dan $\mathrm{S}$, diketahui bahwa alasan yang membuat informan tidak melanjutkan (putus) pengobatan adalah tidak kuat menahan efek samping yang berat. Hal ini dapat diketahui dari kutipan berikut ini:

"begini mas, berhubung waktu saya itu minum obat dari jebres (RSDM), itu kan dari puskesmas dikirim dari jebres, berhubung kondisi saya ini tidak kuat sama sekali mas, saya itu seumpama saya cocok yang minum obat, dah tidak ada sajalah (meninggal), badan saya sudah habis (kurus), kalau minum obat saya itu, boro-boro kok bisa berdiri seperti saat ini, rasanya sakit kepala, mual, muntah, pokoknya sudah tidak karu-karuan rasanya.......

Alasan lain dinyatakan oleh informan $\mathrm{T}$, bahwa alasan tidak bersedia melanjutkan (putus) pengobatan adalah kekecewaan terhadap sikap petugas kesehatan.

Tuberculosis (TBC) adalah penyakit menular lewat udara (air borne disease) yang merupakan salah satu penyebab kematian utama di dunia. TBC adalah penyakit kronik 
dimana salah satu kunci kesuksesan pengobatannya berupa kepatuhan (adherence) pengobatan penderita dalam menelan obat. Selama penderita menjalani pengobatan TBC, terdapat kemungkinan adanya ketidakpatuhan penderita TBC dalam menelan obat. Ketidakpatuhan ini dapat disebabkan oleh beberapa hal, diantaranya adalah perilaku menelan obat dalam jangka waktu yang lama (21 bulan), jumlah obat yang ditelan, serta kurangnya pengetahuan dan sikap dari penderita.

Ketidakmampuan penderita untuk menuntaskan pengobatan dapat mengakibatkan kegagalan pengobatan, dan kekebalan kuman TBC terhadap obat, serta berisiko menular kepada orang disekitar penderita. Obat seharusnya ditelan sesuai dengan anjuran dari dokter terutama pada dua tahap pengobatan agar tidak terjadi kegagalan pengobatan dan kekambuhan.

Hasil penelitian menunjukkan $64 \%$ responden tidak patuh dalam pengobatan TB MDR. Berdasarkan teori L. Green terdapat tiga faktor yang mempunyai pengaruh dalam membentuk perilaku yaitu: 1) Faktor predisposisi berupa pengetahuan, sikap, keyakinan, nilai-nilai, 2) Faktor pendorong berupa sikap petugas kesehatan, 3) Faktor pendukung berupa ketersediaan fasilitas prasarana dan sarana kesehatan.

Kepatuhan penderita berdasarkan keterpaksaan atau tidak paham mengenai pentingnya perilaku, dapat diikuti oleh kepatuhan yang berbeda, diantaranya kepatuhan demi menjaga hubungan yang baik dengan petugas kesehatan atau panutan yang menganjurkan perubahan tersebut (change agent). Kepatuhan terjadi karena penderita merasa tertarik atau mengagumi panutan tersebut, sehingga penderita berusaha mematuhi apa yang dianjurkan dan diinstruksikan tanpa memahami arti dan manfaat dari perilaku, tahap ini disebut sebagai proses identifikasi.

Motivasi untuk melakukan perubahan perilaku dalam tahap ini lebih baik daripada dalam tahap kesediaan, akan tetapi motivasi ini belum dapat menjamin konsistensi perilaku karena penderita belum tentu dapat menghubungkan perilaku tersebut dengan nilai-nilai lain dalam hidup penderita. Perubahan perilaku penderita dapat menjadi baik, apabila perubahan perilaku terjadi melalui proses internalisasi, dimana perilaku yang baru, dianggap memiliki nilai yang baik bagi penderita dan disatukan dengan nilai-nilai lain.

Pada penelitian ini menunjukkan responden yang memiliki sikap baik dan tidak patuh sebesar 5 (18\%), sedangkan responden yang memiliki sikap yang kurang dan tidak patuh sebesar $13(46 \%)$. Berdasarkan hasil uji statistik dengan taraf signifikansi $5 \%$ diperoleh hasil nilai $\mathrm{p}$ sebesar 0,002 dimana $p$ value $<\alpha$, maka Ho ditolak, artinya terdapat hubungan antara sikap tentang pengobatan TB MDR dengan ketidakpatuhan pengobatan TB MDR. Hal ini sesuai dengan teori dari ilmu perilaku kesehatan yang menyebutkan bahwa sikap merupakan salah satu komponen perilaku, dimana perilaku akan mempengaruhi status kesehatan seseorang. Penentuan sikap, keyakinan, dan emosi memiliki peranan penting dalam terbentuknya perilaku. Seperti halnya pengetahuan, sikap juga memiliki hierarki berdasarkan intensitasnya sebagai berikut: bersedia menerima rangsangan (stimulus) yang diberikan (objek), menyampaikan jawaban atau umpan balik terhadap pertanyaan atau objek yang dihadapi, menyampaikan nilai yang positif terhadap suatu objek atau rangsangan, dengan maksud membahasnya dengan orang lain, bahkan mengajak, mempengaruhi serta menganjurkan orang lain untuk memberikan respon (tanggapan), sikap yang paling tinggi tingkatnya adalah memilki tanggung jawab terhadap apa yang menjadi keyakinan ${ }^{29}$. Sikap yang baik akan membuat patuh penderita dalam minum obat. Sikap adalah keteraturan antara bagian-bagian pemikiran (kognitif), perasaan (afektif), dan predisposisi tindakan (konatif) yang saling berhubungan dalam memahami, merasakan, dan berperilaku terhadap suatu objek dilingkungannya. Sikap yang kurang akan berkontribusi dalam ketidakpatuhan pengobatan pada pasien TB MDR. Menurut penelitian umar dkk sikap penderita paru terhadap jalannya 
proses pengobatan akan berpengaruh terhadap kekambuhan atau ketidakkambuhan penderita TB paru tersebut pada akhir pengobatannya.

\section{KESIMPULAN}

1. Tidak ada hubungan antara pengetahuan responden dengan ketidakpatuhan pengobatan pada pasien TB MDR-MDR di RSDM Surakarta (nilai p sebesar 0,456).

2. Terdapat hubungan antara sikap responden dengan ketidakpatuhan pengobatan pada pasien TB MDR-MDR di RSDM Surakarta (nilai p sebesar 0,020).

3. Tidak ada hubungan antara efek samping obat dengan ketidakpatuhan pengobatan pada pasien TB MDR-MDR di RSDM Surakarta (nilai p sebesar 0,544).

4. Tidak ada hubungan antara dukungan keluarga dengan ketidakpatuhan pengobatan pada pasien TB MDR-MDR di RSDM Surakarta (nilai p sebesar 0,070).

5. Efek samping dan sikap petugas kesehatan menyebabkan pasien TB MDR putus dalam menjalani pengobatan TB MDR

\section{SARAN}

1. Peningkatan pelayanan yang lebih baik kepada pasien TB MDR

2. Pemberian KIE yang lebih intensif kepada pasien TB MDR

3. Peningkatan program Kelompok Dukungan Sebaya (KDS)

\section{DAFTAR PUSTAKA}

WHO. Guidelines for the programmatic management of drug-resistant tuberculosis Emergency update. Geneva. WHO Press; 2008.

WHO. Companion handbook to the WHO guidelines for the programmatic management of drug-resistant tuberculosis. Geneva. WHO Press; 2014.

Kemenkes RI. Riset Kesehatan Dasar 2013. Jakarta. Kementrian Kesehatan RI; 2013.

Dinas Kesehatan Provinsi Jawa Tengah. Buku Saku Kesehatan Tri Wulan 3 tahun 2013. Semarang. Dinas Kesehatan Provinsi Jawa Tengah; 2013.

Selamawit Hirpa, Girmay Medhin, Belaineh Girma, Muluken Melese, Alemayehu Mekonen, Pedro Suarez and Gobena Ameni. Determinants of multidrug-resistant tuberculosis in patients who underwent first-line treatment in Addis Ababa: a case control study. BMC Public Health. 2013. 13:782

Laura Jean Podewils, Maria Tarcela S. Gler, Maria Imelda Quelapio, Michael P. Chen. Patterns of Treatment Interruption among Patients with Multidrug-Resistant TB (MDR TB) and Association with Interim and Final Treatment Outcomes. PloS ONE. 2013 Juli.

Vijay S, Kumar P, Chauhan LS, Hanumanthappa B, Kizhakkethil, Rao SG. Risk Factors Associated With Default Among New Smear Positive Tuberkulosis Patients Treated Under DOTS in India. Plos ONE. 2010;5:1-9. 
I Made Bagiada, Ni Luh Putri Primasari. Faktor-Faktor Yang Mempengaruhi Tingkat Ketidakpatuhan Penderita Tuberkulosis Dalam Berobat Di Poliklinik DOTS RSUP Sanglah Denpasar. Jurnal Penyakit Dalam. 2010;11:158-163

Saira Zai, Tyaba Haron, Khawaja Tahir Mehmood. Socioeconomic Factors Contributing Multidrug-Resistant Tuberculosis (MDR-TB). Jounal Biomed Sci and Res. 2010;2:279283

Blanc AT, et al. Management of Chronic and Multi Drug Resistance Case in teratment of tuberculosis: Guidlines for National Programmes, $3^{\text {rd }}$ ed. Geneva. WHO; 2003

Iseman MD. Mycobacterial Disease of The Lungs in Hanley M, Welsh CH (eds), Current diagnosis and Treatment in Pulmonary Medicine. New York. . Mc Graw Hill; 2003

Kemenkes RI. Petunjuk Teknis Manajemen Terpadu Pengendalian Tuberkulosis Resistan Obat 2013. Jakarta. Kemenkes RI; 2013

Kemenkes RI. Terobosan Menuju Akses Universal Strategi Nasional Pengendalian TB Di Indonesia 2010-2014. Jakarta. Kemenkes RI; 2011

Riyanto BS, Wilhan. Management of MDR TB Current and Future dalam Buku Program dan Naskah Lengkap Konferensi Kerja Pertemuan Ilmiah Berkala. Bandung. PERPARI; 2006.

Kemenkes RI. Pedoman Nasional Pelayanan Kedokteran Tata Laksana Tuberkulosis. Jakarta. Kemenkes RI; 2013

Notoatmodjo, Soekidjo. Promosi Kesehatan dan Ilmu Perilaku. Penerbit Rineka Cipta. Jakarta. 2007

Notoatmodjo, Soekidjo. Pendidikan dan Perilaku Kesehatan. Penerbit Rineka Cipta. Jakarta. 2003.

Notoatmodjo, Soekidjo. Ilmu Perilaku Kesehatan. Penerbit Rineka Cipta. Jakarta. 2010

Sarwono, EW. Teori-Teori Sosial, CV. Rajawali, Jakarta; 1993

Green, L.W, et al. 1980. Health Education Planning: a Diagnosyic Approach.Mayfield Publishing Company, Palo Alto, California

Ubaidillah. Faktor Yang Mempengaruhi Ketidakteraturan Berobat Penderita TB Paru Di Kabupaten Lahat Propinsi Sumatera Selatan. (Tesis). Jakarta. FKM UI; 2011

Sabate E. WHO Adherence meeting report. WHO. Geneva; 2001

WHO. Adherence to long-term therapies: Evidence for Action. WHO. Geneva; 2003

Notoatmojo, Soekidjo. Metodologi Penelitian Kesehatan. Penerbit Rineka Cipta Jakarta; 2010. 
Stanley Lemeshow, David W Hosmer Jr, Janelle Klar. Besar Sampel dalam Penelitian. Gajah Mada University Press. Yogyakarta; 1997

Syukra, Alhamda. Buku Ajar Sosiologi Kesehatan. Deepublish. Yogyakarta; 2015

Becker M.H, Psychossosial Aspect of Health Related Behaviour, 1979.

Erni Erawatyningsih, Purwanta, Heru Subekti. Faktor-Faktor Yang Mempengaruhi Ketidakpatuhan berobat Pada Penderita Tuberkulosis Paru. Jurnal Berita Kedokteran Masyarakat.2009. Vol. 25, No. 3.

Bart Smet, Psikologi kesehatan, PT Gramedia Widiasarana Indonesia, Jakarta. 1994. CDC. Reported Tuberculosis in the United States, 2008. Atlanta, GA: U.S. Department of Health and Human Services, CDC, September 2009.

Priska P. H Kondoy,Dina V Rombot, Henry M.F Palandeng, Trevino A Pakasi. Faktor-Faktor Yang Berhubungan Dengan Kepatuhan Berobat Pasien Tuberkulosis Paru di Lima Puskesmas di Kota Manado. Jurnal Kedokteran Komunitas Tropik. 2014. Vol II No 1

Priska P. H Kondoy,Dina V Rombot, Henry M.F Palandeng, Trevino A Pakasi. Faktor-Faktor Yang Berhubungan Dengan Kepatuhan Berobat Pasien Tuberkulosis Paru di Lima Puskesmas di Kota Manado. Jurnal Kedokteran Komunitas Tropik. 2014. Vol II No 1.

Sianturi, Ruslanti. Analisis Faktor Yang Berhubungan Dengan Kekambuhan TB Paru (Studi Kasus di BKPM Semarang Tahun 2013). Unnes Journal Of Public Health. 2014. Vol 3 No 1.

Azwar, Saifuddin. Sikap Manusia Teori dan Pengukurannya. Pustaka Pelajar Yogyakarta. 1995

Erni Erawatyningsih, Purwanta, Heru Subekti. Faktor-Faktor Yang Mempengaruhi Ketidakpatuhan Berobat Pada Penderita Tuberkulosis Paru. Berita Kedokteran Masyarakat.2009. Vol 2 No 3

Aditama TY, Sepuluh masalah TB dan penanggulangannya, Jurnal Respirasi Indonesia, 2000;20(1):8-12.

Pandit N, Choudhary SK. A Study of treatment compliance in directly observed therapy for tuberculosis. Indian J Comm Med. 2006;31(4):241-3.

Hutapea TP. Pengaruh dukungan keluarga terhadap kepatuhan minum obat anti tuberkulosis. Jurnal respirologi Indonesia; 2009. Vol: 29 (2).

Niven, N. Psikologi kesehatan: Pengantar untuk perawat \& professional kesehatan lain. EGC. Jakarta. 2012

Murtiwi.Keberadaan Pengawasan Minum Obat (PMO) Pasien Tuberculosis Paru di Indonesia.Jurnal Keperawatan Indonesia, 2006. Vol: 10: 1 
Nugroho, Kristiawan Prasetyo Agung, Fitrianto Agus, Anugerahni, Harni Seyla. Pengetahuan Keluarga Terkait Faktor Penyebab Kekambuhan Pada Penderita TB MDR Di Rumah Sakit Paru Dr. Ario Wirawan Salatiga.Jurnal KesMaDaSka, 2018. Vol: 1:1

Kristiono R.S, Wardani Yuniar. Faktor-Faktor Yang Berhubungan Dengan Pola Pencarian Pengobatan Ke Pelayanan Kesehatan Alternatif Pasien Suspek Tuberculosis Di Komunitas. Jurnal KESMAS, 2013. Vol: 7: 2 